\title{
A New Scale of Basicity in Oxide Slag and the Basicity of the Slag Containing Amphoteric Oxides*
}

By Kazumi Mori**

\section{Introduction}

The acidic or basic behavior of slag-forming oxides and the basicity of slag have an important bearing on the iron- and steel-making processes. In most cases some ratio of the amounts of basic oxides to those of acidic oxides has been used as a measure of basicity, but it is only an empirical measure and cannot be considered a real measure of chemical properties. Moreover, in the expression of slag basicity little attention has been paid to the behavior of amphoteric oxides such as $\mathrm{Al}_{2} \mathrm{O}_{3}$ and $\mathrm{TiO}_{2}$. Thus, defining and measuring the slag basicity in a theoretically satisfactory manner has been an unsolved problem. It is from this aspect that the author has an interest in the subject.

In the present report a new scale of basicity is given, based on the fact that the ratio of ferric to total iron $\left(\mathrm{Fe}^{3+} / \sum \mathrm{Fe}\right.$ ) in oxide slag is greatly affected by the change in basicity, together with the method of experimental determination of the basicity values and the results of the study on slag containing amphoteric oxides.

\section{General Review of the Slag Basicity}

The most conventional expression of slag basicity, which is implied as the strength of base in the slag, has been $V=\left(\begin{array}{ll}\% & \mathrm{CaO}\end{array}\right) /\left(\begin{array}{ll}\% & \mathrm{SiO}_{2}\end{array}\right)$ or $V$, $=\sum(\%$ base $) / \sum(\%$ acid $)$. In some cases in the $V$ 'ratio some factors relating to the relative acidbase strength of the oxides were given in the weight percentage.1)2) "Excess base" expressed by Grant and Chipman") or the "concentration of free oxygen ions" devised by Herasymenko and Speight ${ }^{4}$ could also be used as the expression of slag basicity. The common factors in these expressions of slag basicity are that the constituent oxides were classified distinctly either as acidic or as basic and that based on this classification the basicity value was calculated in an arithmetical manner from slag analyses. However, since such a procedure to express slag basicity is not based on theoretical arguments, it is difficult to understand what is implied theoretically by the basicity thus expressed.

On the other hand, in the purely fundamental field of physical chemistry, various definitions have been given to the concept of acid and base by Arrhenius, Germann, Brönsted, Lewis, Usanovich and Bjerrum. Of these definitions, Usanovich's definition is most easily applied to oxide and slag

* Lecture delivered before the 53rd \& 55th Grand Lecture Meeting April 1957, 1958 in Tokyo. Tetsu-to-Hagané (Journal, Iron \& Steel Institute, Japan) Vol. 46, No. 4 pp. $466-473$

** Assistant Professor, Department of Metallurgy, Faculty of Engineering, Ibaraki University. systems. According to this definition, an "acid" is either a donor of protons (or cations) or an acceptor of electrons (or anions), while a "base" is either a donor of electrons (or anions) or an acceptor of protons (or cations). Based on this theory, a definition of acid-base for oxide and slag systems may be made as follows: A basic oxide is one that can donate oxygen ions, while an acidic oxide is one that can accept oxygen ions from basic oxides. Such a definition has already been made with glass systems by Sun and Silverman $\left.{ }^{5}\right)^{6)}$ and with slag systems by Chipman and Chang ${ }^{7)}$.

On the basis of this definition, it is possible to express the scale of basicity or acidity for pure oxides by the strength of the metal-oxygen (M-O) bond. Sun, ${ }^{(6) 8)}$ using thermal data, estimated the relative M-O bond strength, which he identified with the scale of basicity or acidity of oxides. An analogous scale may be expressed by the binding energy between a cation and an oxygen ion represented by:

$$
I=2 z / a^{2}
$$

where $z$ is the charge of the cation and $a$ is the distance between the cation and the oxygen ion. The larger $I$ value an oxide has, the stronger is its acidic property (or the weaker its basic property). The experimental value of acid-base strength of oxides could be obtained from the coloring transition point in glass or from the measurement of e.m.f. in the cell where molten glass was used as the electrolyte. ${ }^{9)}$

Thus, based on the fundamental definition by Usanovich, the definite concept for the basicity of pure cxides has been well established. However, this idea of basicity has not been taken into consideration in the conventional expression of basicity in multicomponent systems. It is the chief object of this paper to give a new scale of basicity which is able to deal with pure oxides as well as multicomponent oxide systems on the same ground.

\section{A New Scale of Basicity and Its Measure- ments}

\section{A New Scale of Basicity}

Because oxide slag contains large amounts of oxygen ions, it seems most reasonable to express the slag basicity by the oxygen-ion activity. The oxygen-ion activity may be obtained from the measurement of e.m.f. by the methods developed by $\operatorname{Lux}^{10)}$ and Didtschenko and Rochow. ${ }^{9)}$ However, the measurement on general slag systems will be extremely difficult.

It is well-known that the ratio of ferric to total iron $\left(\mathrm{Fe}^{+3} / \sum \mathrm{Fe}\right)$ in oxide slag is increased with increase of the basicity of added slag under con- 
stant oxygen pressure. ${ }^{11) \sim 13)}$ This phenomenon might be derived from the fact that the iron ratio is affected by the compound strength of $\mathrm{M}-\mathrm{O}$ bonds relating to the constituent cations other than ferric and ferrous ions. Since, as described in the previous section, the $\mathrm{M}-\mathrm{O}$ bond strength itself is the scale of basicity for pure oxides, this phenomenon has been chosen in the present paper to measure the basicity of slag, as was suggested by Larson and Chipman. ${ }^{1: 3)}$

Since oxygen ions are common to all the components in an oxide slag system, it is adequate to use ionic fraction of cations in the expressions of the concentration of the added slag, of which the basicity is to be determined. Then the concentration of the added slag $(C)$ is represented by the expression:

$$
\begin{aligned}
& C=\sum \mathrm{M} /\left(\sum \mathrm{Fe}+\sum \mathrm{M}\right) \\
& \sum \mathrm{Fe}=\mathrm{Fe}^{2+}+\mathrm{Fe}^{3+} \\
& \sum \mathrm{M}=\mathrm{Ca}^{2+}+\mathrm{Si}^{4+}+\mathrm{Ti}^{4}+\mathrm{Al}^{3+}+\cdots \cdots
\end{aligned}
$$

Since in general the ratio:

$$
r=\mathrm{Fe}^{3+} /\left(\mathrm{Fe}^{2+}+\mathrm{Fe}^{3+}\right)
$$

changes with $C$, it is not adequate to choose $r$ at some concentration as the scale of basicity. Therefore, the gradient of an $r$-C curve at the infinitely dilute concentration, or $(d r / d C)_{c \rightarrow 0}$, was chosen as the scale of basicity. In the concentration range where $r$ changes linearly with $C,(d r / d C)_{c-0}$ may be put in the following form:

$$
(d r / d C)_{c \rightarrow 0}=\left(r-r_{0}\right) / C
$$

which is independent of $C$. Here $r_{0}$ represents the $r$ of the pure iron oxide.

According to the study by Larson and Chipman, ${ }^{13)}$ a linear relationship between $r$ and $C$ seems to be approximately established below $20-25 \mathrm{~mol} \%$ of the added slag. In the present study, based on the assumption of linear relationship between $r$ and $C$, the scale of basicity is given by the equation:

$$
B=\left\{\left(\boldsymbol{r}-\boldsymbol{r}_{0}\right) / C\right\} \times 10
$$

in which the numeral 10 serves to make the $B$ value disposable.

\section{Experimental Method}

The experimental procedure used in this study is as follows: the iron oxide with small additions of the slag whose basicity is to be determined was equilibrated with a gaseous atmosphere of $\mathrm{CO}_{2}$ $\mathrm{CO}=13.3 . \quad\left(\mathrm{Po}_{2}=2.87 \times 10^{-6} \mathrm{~atm}\right)$ at a temperature of $1480^{\circ} \mathrm{C}$, and the quenched samples were subject to chemical analysis.

The design of the furnace is shown schematically

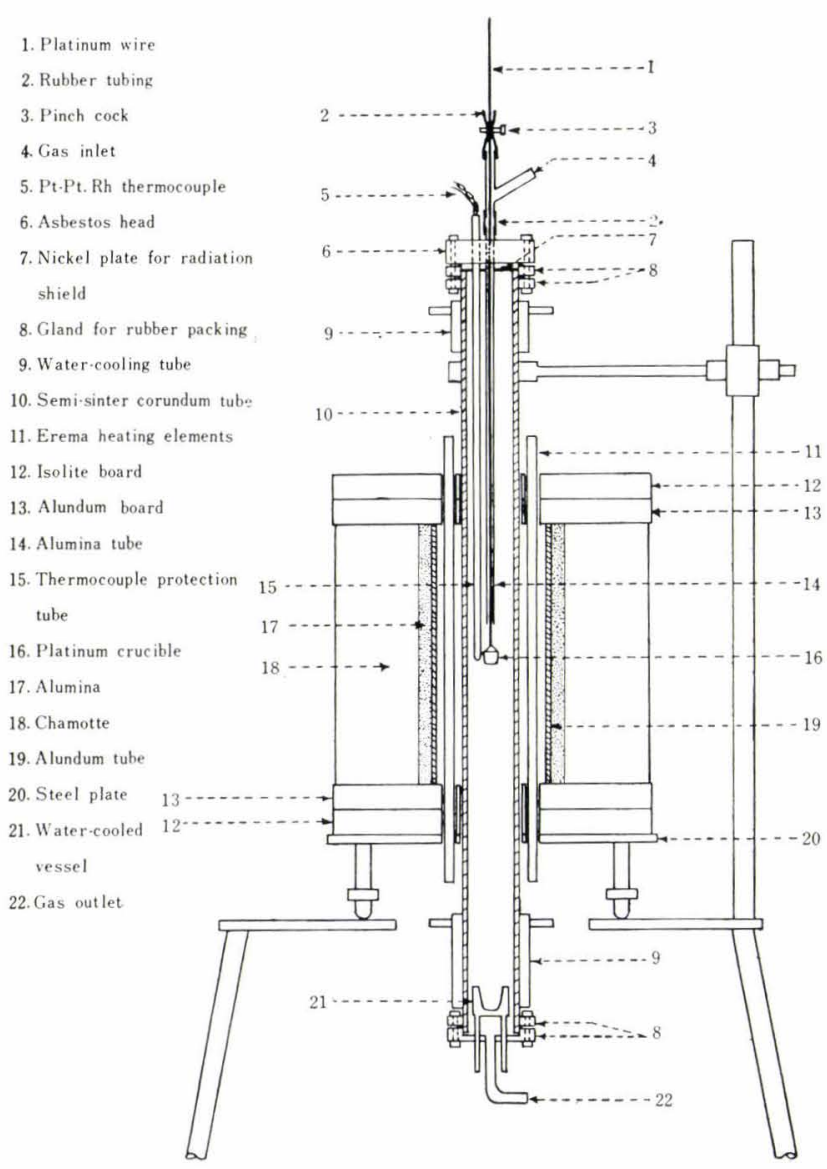

Fig. 1 Experimental furnace

in Fig. 1. The heating element consisted of six Erema rods ( $\mathrm{SiC}$ ). Along the center of the furnace was a semi-sinter corundum tube. A small platinum crucible with a capacity of $1 \mathrm{cc}$ was suspended on a platinum wire inside the tube. In this crucible $1.5 \mathrm{~g}$ sample was melted.

Samples were prepared by mixing ferrous oxide with the slag whose basicity is to be determined. Ferrous oxide material was made by melting ferric oxide reagent in an iron crucible.

The $\mathrm{CO}_{2}$-CO gas mixture, which passed through calcium chloride, copper at $500^{\circ} \mathrm{C}$ and phosphorous pentoxide, was analyzed by the Orsat gas analysis apparatus. After the temperature of the furnace was raised to $1150^{\circ} \mathrm{C}$, the platinum crucible was suspended and the furnace tube was sealed. Then the tube was evacuated and immediately the prepared gas mixture was introduced into the furnace tube. At the same time the temperature was again raised rapidly to $1480^{\circ} \mathrm{C}$. All runs were conducted for about 3 hrs, during which time the gas mixture passed at the flow rate of $100 \mathrm{cc}$ per min. When the slag had reached an equilibrium, the crucible 
was quenched by being lowered rapidly until it reached the water-cooled vessel at the bottom of the furnace tube. The sample was crushed carefully in an agate mortar and analyzed for ferrous and ferric iron. From the analytical results the basicity value was calculated by the eq. (4).

\section{Basicity of Slag Containing Titanium Oxide}

The studied systems are as follows: $\mathrm{CaO}, \mathrm{SiO}_{2}$, $\mathrm{TiO}, \mathrm{CaO}-\mathrm{SiO}_{2}, \mathrm{CaO}-\mathrm{TiO}_{2}, \mathrm{SiO}_{2}-\mathrm{TiO}_{2}, \mathrm{CaO}-\mathrm{SiO}_{2}-\mathrm{TiO}_{2}$. Samples used in this study consisted of $80 \mathrm{~mol} \%$ $\mathrm{FeO}$ and $20 \mathrm{~mol}^{\%}$ slag in question. Fig. 2 shows the basicity of three binary systems. The values of the basicity for $\mathrm{CaO}, \mathrm{SiO}_{2}$ and $\mathrm{TiO}_{2}$ are such as would be expected from the scale of basicity given by Sun ${ }^{(i) s)}$ and the metal-oxygen bond strength (I). The acid-base property of $\mathrm{TiO}_{2}$ as a pure oxide is rather similar to that of $\mathrm{SiO}_{2}$, though the acid strength of $\mathrm{TiO}_{2}$ is somewhat weaker than that of $\mathrm{SiO}_{2}$.

In the systems $\mathrm{CaO}-\mathrm{SiO}_{2}$ and $\mathrm{CaO}-\mathrm{TiO}_{2}$, the basicity changes approximately linearly with $\operatorname{mol}^{\%} \%$. Comparison between these two systems reveals that $\mathrm{TiO}_{2}$ has the same behavior as $\mathrm{SiO}_{2}$. On the other hand, in the system $\mathrm{SiO}_{2}-\mathrm{TiO}_{2}$ a considerably different curve appears, showing a maximum at nearly $50 \mathrm{~mol}_{\%} \mathrm{TiO}_{2}$.

In Fig. 3 the basicity of the $\mathrm{CaO}-\mathrm{SiO}_{2}-\mathrm{TiO}_{2}$ ternary system is shown in terms of isobasicity lines plotted on the ternary diagram (in wt\%). Isobasicity line for $B=-2.2$ below $40 \% \mathrm{TiO}_{2}$ coincides with the line of constant $\mathrm{CaO} / \mathrm{SiO}_{2}$, which shows that at the constant $\mathrm{CaO} / \mathrm{SiO}_{2}$, the basicity does
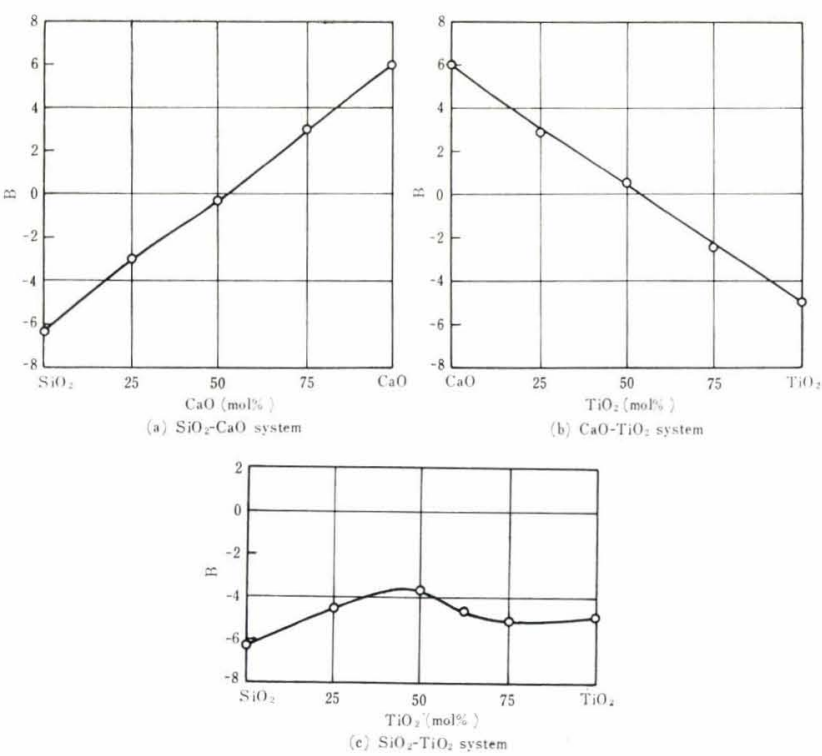

Fig. 2 Basicity of binary systems

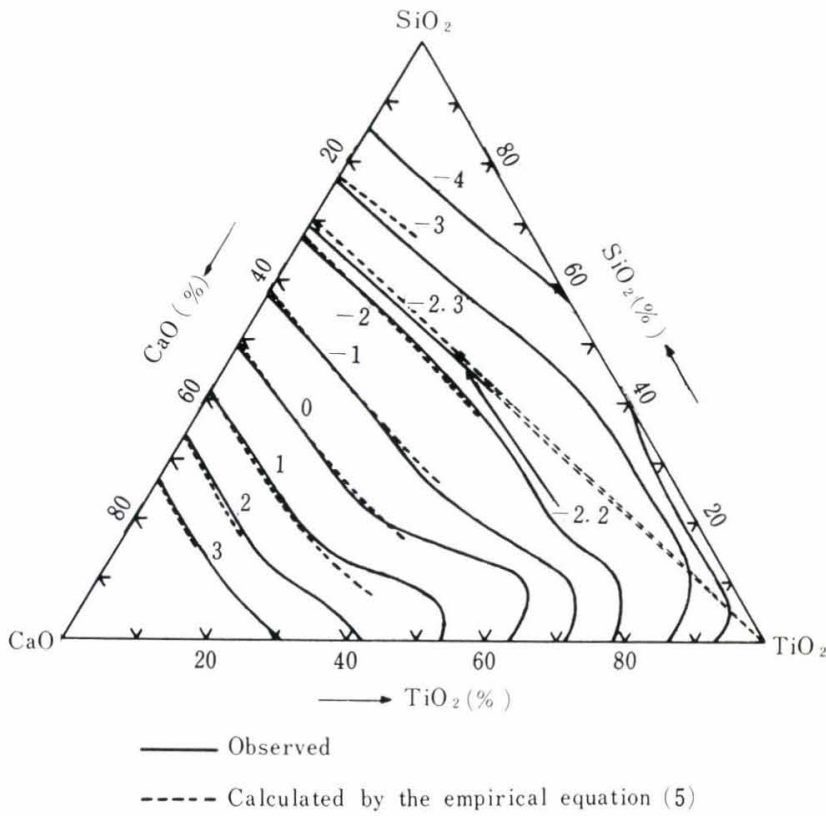

Fig. 3 Isobasicity lines in the $\mathrm{CaO}-\mathrm{SiO}_{2}-\mathrm{TiO}_{2}$ system

not change with additions of $\mathrm{TiO}_{2}$. At lower ratios of $\mathrm{CaO} / \mathrm{SiO}_{2}$, basicity $(B)$ is increased by additions of $\mathrm{TiO}_{2}$ along the lines of the constant $\mathrm{CaO} / \mathrm{SiO}_{2}$ and at higher ratios decreased. This is a very interesting fact, because it shows the so-called amphoteric behavior that an amphoteric oxide added to an acidic slag behaves as a base and it behaves as an acid when added to a basic slag. However, at higher ranges of $\mathrm{TiO}_{2}$ the feature of the isobasicity curve changes in such a way that the basicity rapidly draws near that of $\mathrm{TiO}_{2}$ itself.

For the $\mathrm{CaO}-\mathrm{SiO}_{2}-\mathrm{TiO}_{2}$ system the empirical equations have been obtained as follows:

$$
\begin{aligned}
& B=-17.95 /[1.45+(\mathrm{CaO}) / \\
&\left.\left\{\left(\mathrm{SiO}_{2}\right)+f_{T}\left(\mathrm{TiO}_{2}\right)\right\}\right]+7.27 \\
& f_{T}=g_{T}\left\{\left(\mathrm{CaO} / \mathrm{SiO}_{2}\right)\right\} \cdot h_{T}\left\{\left(\mathrm{TiO}_{2}\right)\right\} \\
&=\left[-1 /\left\{0.005+\left(\mathrm{CaO} / \mathrm{SiO}_{2}\right)\right\}+2.350\right] \cdot \\
& \quad\left\{-0.0066\left(\mathrm{TiO}_{2}\right)+0.598\right\}
\end{aligned}
$$

where concentrations are expressed in wt . These equations hold good in the concentration range $\mathrm{CaO} / \mathrm{SiO}_{2}=1 / 3-4, \mathrm{TiO}_{2}=0-35 \%$. The dotted lines in Fig. 3 are isobasicity lines corresponding to the empirical equations. In eq. (5), considering the similar acid-base behavior of pure $\mathrm{TiO}_{2}$ to that of $\mathrm{SiO}_{2}$, the weight percentage of $\mathrm{TiO}_{2}$ is put in the denominator of the fraction relating to concentration, being multiplied by the factor $f_{T}$. This factor could be expressed by the product of a function of $\mathrm{CaO} / \mathrm{SiO}_{2}\left(g_{T}\right)$ and that of $\mathrm{TiO}_{2}$ wt $\left(h_{T}\right)$ as shown by eq. (6). Fig. 4 illustrates the relation between the factor $f_{T}$ and $\mathrm{CaO} / \mathrm{SiO}_{2}$ at $\mathrm{TiO}_{2} 20 \%$ for the $\mathrm{CaO}-\mathrm{SiO}_{2}-\mathrm{TiO}_{2}$ system. 


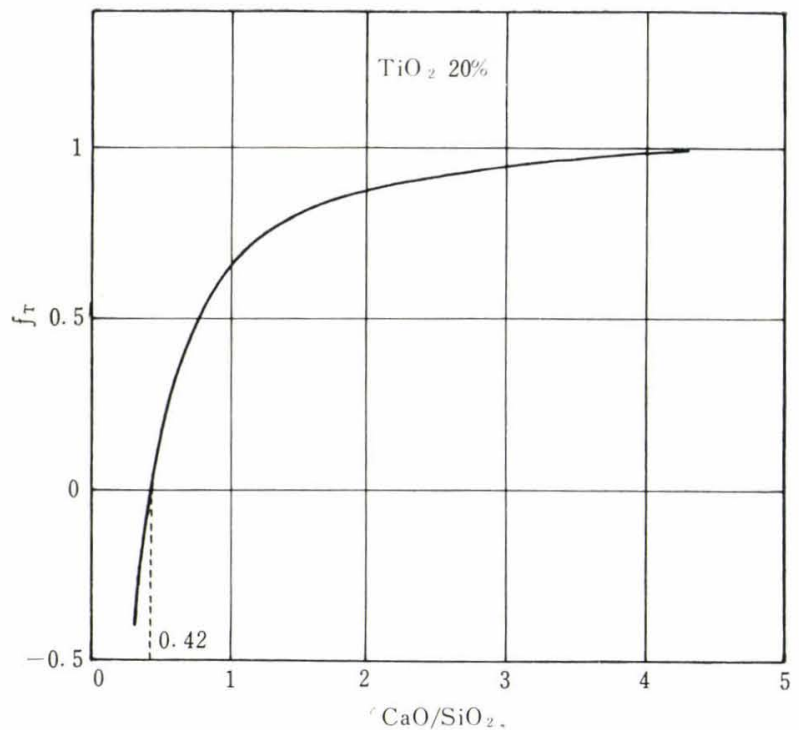

Fig. 4 Change of the factor $f_{T}$ with $\mathrm{CaO} / \mathrm{SiO}_{2}$

Though eqs. (5) and (6) have been obtained as empirical equations, they will give some suggestion to the theoretical consideration of basicity. According to the curve in Fig. 4, the $f_{T}$ value is found to be zero at $\mathrm{CaO} / \mathrm{SiO}_{2}=0.42$. It is positive in the range where $\mathrm{CaO} / \mathrm{SiO}_{2}>0.42$, while it is negative in the range where $\mathrm{CaO} / \mathrm{SiO}_{2}<0.42$. The former indicates the acidic behavior of $\mathrm{TiO}_{2}$, while the latter indicates the basic behavior.

The author thus arrived at this conclusion: Although titanium-dioxide itself is classified as an acidic oxide like silica, in the ternary system $\mathrm{CaO}$ $\mathrm{SiO}_{2}-\mathrm{TiO}_{2}\left(\mathrm{TiO}_{2}<40 \%\right)$ it is regarded as an amphoteric oxide. This amphoteric behavior of $\mathrm{TiO}_{2}$ could be expressed quantitatively in terms of $f_{T}$.

\section{Basicity of Slag Containing Alumina}

Next the experimental results on the slag containing alumina, which is a typical amphoteric oxide, will be described. The studied systems were as follows: $\mathrm{CaO}-\mathrm{Al}_{2} \mathrm{O}_{3}, \mathrm{SiO}_{2}-\mathrm{Al}_{2} \mathrm{O}_{3}$ and $\mathrm{CaO}-\mathrm{SiO}_{2}-$ $\mathrm{Al}_{2} \mathrm{O}_{3}$. The melting point of iron oxide containing alumina rose sharply with increase of alumina content and it was impossible in this work to obtain the basicity for a concentration range above $25 \mathrm{~mol}_{\%} \mathrm{Al}_{2} \mathrm{O}_{3}$. Samples used in this study consisted of $85-90 \mathrm{~mol}^{\circ} \mathrm{FeO}$ and $10-15 \mathrm{~mol} \%$ slag containing alumina.

Naturally, in the $\mathrm{CaO}-\mathrm{Al}_{2} \mathrm{O}_{3}$ system the basicity was decreased by additions of $\mathrm{Al}_{2} \mathrm{O}_{3}$, while in the $\mathrm{SiO}_{2}-\mathrm{Al}_{2} \mathrm{O}_{3}$ system it was increased.

Fig. 5 shows the isobasicity lines in the $\mathrm{CaO}$ $\mathrm{SiO}_{2}-\mathrm{Al}_{2} \mathrm{O}_{3}$ system. The isobasicity line of $\mathrm{B}=$ -0.2 coincides with the line of $\mathrm{CaO} / \mathrm{SiO}_{2}=1$, where the basicity does not change with the addition of alumina. At lower ratios of $\mathrm{CaO} / \mathrm{SiO}_{2}$ the basicity

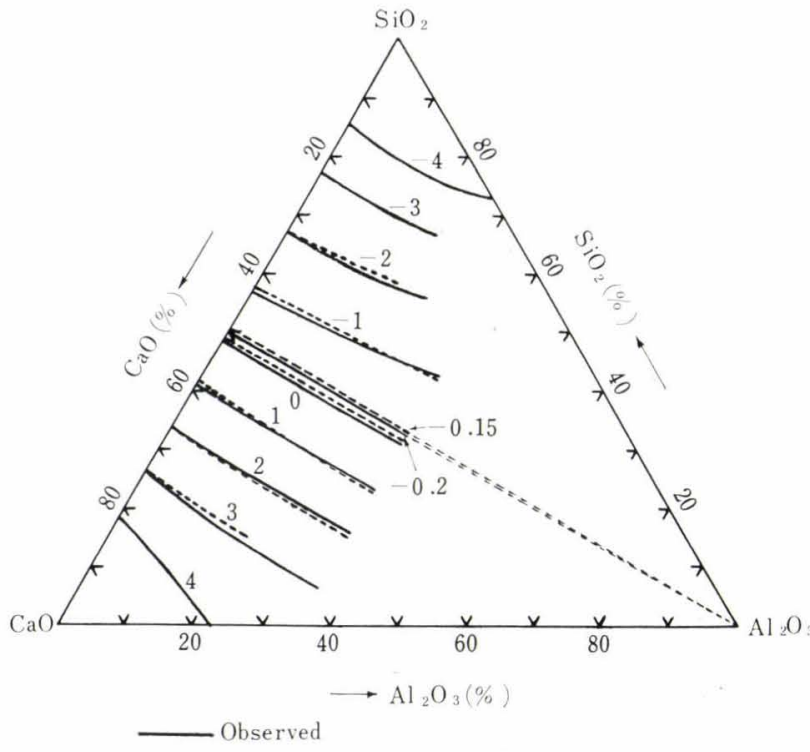

-..- Calculated by the empirical equation 7

Fig. 5 Isobasicity lines in the $\mathrm{CaO}-\mathrm{SiO}_{2}-\mathrm{Al}_{2} \mathrm{O}_{3}$

is increased by additions of $\mathrm{Al}_{2} \mathrm{O}_{3}$ along the lines of the constant $\mathrm{CaO} / \mathrm{SiO}_{2}$ and at higher ratios decreased. That is, the same amphoteric behavior of $\mathrm{Al}_{2} \mathrm{O}_{3}$ as that of $\mathrm{TiO}_{2}$ has been shown to be evident. In this case, it should also be noted that the boundary line classifying the acidic and basic behavior coincided with the line of $\mathrm{CaO} / \mathrm{SiO}_{2}=1$.

As an expression of the correlation between the basicity and the concentration, the following empirical equations were obtained:

$$
\begin{aligned}
B= & -17.95 /[1.45+(\mathrm{CaO}) / \\
& \left.\left\{\left(\mathrm{SiO}_{2}\right)+f_{A}\left(\mathrm{Al}_{2} \mathrm{O}_{3}\right)\right\}\right]+7.27 \\
f_{A}= & g_{A}\left\{\left(\mathrm{CaO} / \mathrm{SiO}_{2}\right\} \cdot h_{A}\left\{\left(\mathrm{Al}_{2} \mathrm{O}_{3}\right)\right\}\right. \\
= & {\left[-1 /\left\{0.089+\left(\mathrm{CaO} / \mathrm{SiO}_{2}\right)\right\}+0.955\right] \cdot } \\
& \left\{-0.0103\left(\mathrm{Al}_{2} \mathrm{O}_{3}\right)+0.810\right\}
\end{aligned}
$$

These equations hold good in the concentration range $\mathrm{CaO} / \mathrm{SiO}_{2}=1 / 3-4, \mathrm{Al}_{2} \mathrm{O}_{3}=0-35 \%$. The dotted lines in Fig. 5 are isobasicity lines plotted from the eqs. (7) and (8). The forms of these equations are the same as those of eqs. (5) and (6).

In eq. (7) the weight percentage of $\mathrm{Al}_{2} \mathrm{O}_{2}$ is put in the denominator of the fraction relating to concentration, being multiplied by the factor $f_{A}$. Although in this case it is likewise permitted to put $\mathrm{Al}_{2} \mathrm{O}_{3}$ concentration in the numerator, eq. (7) was obtained by adopting the conventional idea that the acid-base property of $\mathrm{Al}_{2} \mathrm{O}_{3}$ resembles that of $\mathrm{SiO}_{2}$ rather than $\mathrm{CaO}$.

Concerning the relationship between the factor $f_{A}$ and $\mathrm{CaO} / \mathrm{SiO}_{2}$, a curve analogous to that shown in Fig. 4 was obtained. In this case, however, the value of $f_{A}$ was found to be zero at $\mathrm{CaO}$ $\mathrm{SiO}_{2}=0.96$, and it was positive in the range where 
$\mathrm{CaO} / \mathrm{SiO}_{2}>0.96$, while it was negative in the range where $\mathrm{CaO} / \mathrm{SiO}_{2}<0.96$. Thus it was found that the amphoteric behavior of $\mathrm{Al}_{2} \mathrm{O}_{3}$ could be expressed quantitatively by the factor $f_{A}$.

\section{Discussions}

\section{Properties of the Newly Defined Basicity}

The newly defined basicity is characteristic in two ways. In the first place, basicity of a pure oxide as well as that of any multicomponent oxide slag can be expressed on the same scale. Secondly, in principle, values of the new basicity can be obtained only by an actual measurement, which is very different from the conventional expression. The basicity, in its real nature, has no concern with the form of constituent ions in slag. In this way the new basicity very much resembles a thermodynamic function.

Accordingly, the basicity will reveal its real nature in the chemical reaction between metal and slag. Recently the author worked on the reduction of Ti and Si from the molten slag containing titanium oxide to carbon-saturated iron and succeeded in explaining the results based on the new basicity. As for this work, the author's other reports ${ }^{14) 15)}$ should be referred to.

In aqueous chemistry a solution is classified as acidic or basic or neutral according to the $\mathrm{pH}$ value as compared with $\mathrm{pH}=7$. Similarly, in oxide slag systems, the classification can be made as follows:

$$
\left.\begin{array}{ll}
B>0 & \text { basic } \\
B=0 & \text { neutral } \\
B<0 & \text { acidic }
\end{array}\right\}
$$

As will be seen from Fig. 2 (a), the classification given in (9) approximately agrees with the conventional one, which has usually been made according to $\mathrm{CaO} / \mathrm{SiO}_{2} \gtrless 1$.

\section{The Behavior of Amphoteric Oxides}

Up to the present much information has been obtained as to what was implied by acidic or basic, but little has been known of amphoteric. Now it is possible to obtain some insight into the nature of the amphoteric oxides. The behavior of the amphoteric oxides which has been described has a quite analogous aspect to that of aqueous solutions.

When the amphoterite electrolyte is dissolved in an aqueous solution, it behaves as an acid or a base, depending on the $\mathrm{pH}$ value. At a certain concentration of the hydrogen ion, which is termed the "isoelectric point," additions of an amphoterite bring on no change of the $\mathrm{pH}$ value. If the solution is more acidic, the added amphoterite behaves as a base, and if the solution is more basic, it behaves as an acid. At the isoelectric point, the degree of electrolytic dissociation of the amphoterite as an acid equals to that as a base and the concentration of undissociated molecule shows a maximum value. The concentration of the hydrogen ion at the isoelectric point is given by:

$$
\left[H^{+}\right]_{i}=\sqrt{ }\left(k_{a} / k_{b}\right) K_{w}
$$

where $k_{a}, k_{b}$ : the constant of electrolytic dissociation as acid or base

$K_{w}$ : the constant of electrolytic dissociation of water

In slag, as mentioned before, $f_{T}$ or $f_{A}$ value becomes zero at a certain $\mathrm{CaO} \mathrm{SiO}_{2}$, where there is no change of basicity by addition of the amphoteric oxides, just as in the case of aqueous solutions. Accordingly it is also possible to apply the definition of the isoelectric point in aqueous solutions to the slag systems. The basicity corresponding to the isoelectric point is represented by $\mathrm{Bi}$. Isoelectric points in the $\mathrm{CaO}-\mathrm{SiO}_{2}$ system with additions of $\mathrm{TiO}_{2}$ or $\mathrm{Al}_{2} \mathrm{O}_{3}$ as the third component are illustrated in Table 1.

Table 1. Isoelectric points

\begin{tabular}{ccccc} 
Slag system & Observed values & $\begin{array}{l}\text { Values calculated from } \\
\text { the empirical equations }\end{array}$ \\
\hline $\mathrm{CaO} \mathrm{SiO}_{2}-\mathrm{TiO}_{2}$ & 0.45 & -2.2 & 0.42 & -2.3 \\
$\mathrm{CaO}-\mathrm{SiO}_{2}-\mathrm{Al}_{2} \mathrm{O}_{3}$ & 1 & -0.2 & 0.96 & -0.15
\end{tabular}

Thus, it has been shown for the first time that the so-called amphoteric behavior can be quantitatively described in terms of the isoelectric point. Namely, it follows that an amphoteric oxide behaves as a base in a more acidic slag than the isoelectric point, while in a more basic slag it behaves as an acid.

Here the author must make a few remarks about the difference between the isoelectric point and the neutral point. In aqueous solutions, as a rule, an amphoterite itself does not have a neutral behavior and the isoelectric point does not correspond to the neutral point. This is quite in conformity with the amphoteric behavior of $\mathrm{TiO}_{2}$, whose isoelectric point has its location in the considerable acidic range. On the other hand, in the case of $\mathrm{Al}_{2} \mathrm{O}_{3}$ the isoelectric point nearly coincides with the neutral point.

The location of the isoelectric point may depend upon the acid-base strength of the amphoteric oxide. In Fig. 6 the isoelectric point $(B i)$ is plotted against the strength of the metal-oxygen bond which is a measure of the acid-base strength of 
pure oxides. It is conceivable from Fig. 6 that the basicity of the isoelectric point is decreased with increase of the acid strength. It seems to

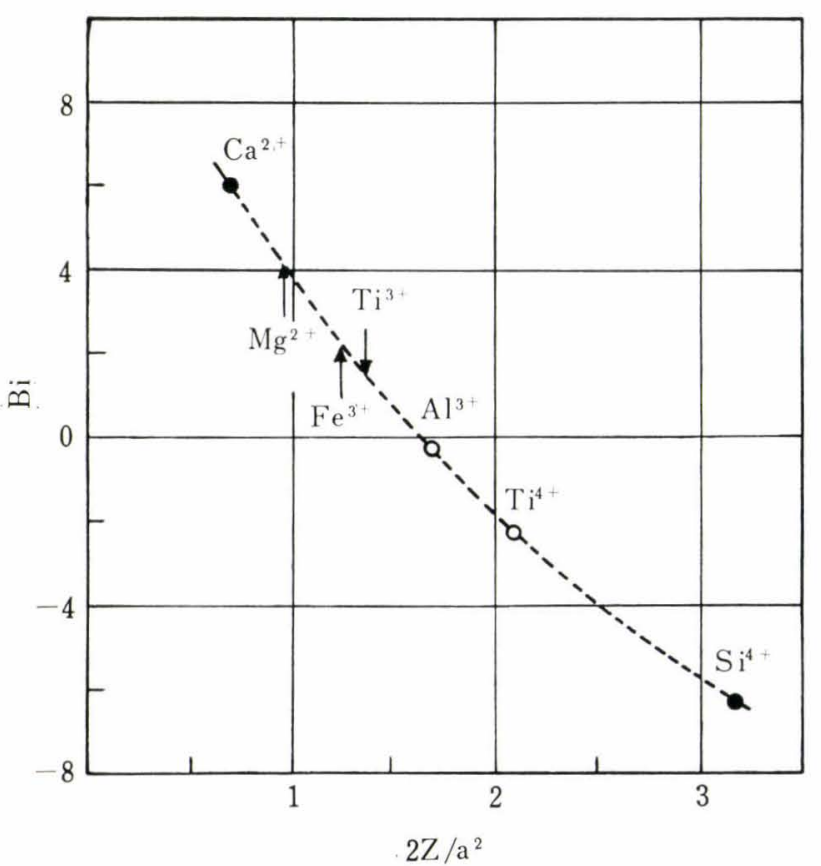

Fig. 6 Relation between the basicity corresponding to the isoelectric point and the strength of the metaloxygen bond

be possible that from this figure such an unknown value of the isoelectric point as that of $\mathrm{Mg}^{2+}, \mathrm{Fe}^{3+}$, or $\mathrm{Ti}^{3+}$ will be estimated.

\section{Summary}

The results obtained in this study are summarized as follows:

(1) After a review of the concepts of slag basicity was made, the well-known fact that the ratio of ferric to total iron in oxide slag is greatly affected by changes in basicity was selected to give the new scale of basicity.

(2) Iron oxide with small additions of the slag whose basicity is to be determined was equilibrated under an atmosphere of $\mathrm{CO}_{2} / \mathrm{CO}=13.3$ at a temperature of $1480^{\circ} \mathrm{C}$. The basicity value $(B)$ was determined from the results of the analyses for $\mathrm{Fe}^{2+}$ and $\mathrm{Fe}^{3+}$.

(3) The $B$ values for $\mathrm{CaO}, \mathrm{SiO}_{2}$ and $\mathrm{TiO}_{2}$ are such as would be expected from the metal-oxygen bond strength. In the systems $\mathrm{CaO}-\mathrm{SiO}_{2}$ and $\mathrm{CaO}-\mathrm{TiO}_{2}$, $B$ changes approximately linearly with $\mathrm{mol}^{\%}$, but in the system $\mathrm{SiO}_{2}-\mathrm{TiO}_{2}$ a maximum appears. The basicity of $\mathrm{CaO}$ is decreased by additions of $\mathrm{Al}_{2} \mathrm{O}_{3}$, while that of $\mathrm{SiO}_{2}$ is increased.
(4) Isobasicity lines of the systems $\mathrm{CaO}-\mathrm{SiO}_{2}$ $\mathrm{TiO}_{2}$ and $\mathrm{CaO}-\mathrm{SiO}_{2}-\mathrm{Al}_{2} \mathrm{O}_{3}$ are shown in ternary diagrams. The empirical equations of basicity were obtained for the concentration range $\mathrm{CaO}$ $\mathrm{SiO}_{2}=1 / 3-4$ and $\mathrm{TiO}_{2}$ (or $\mathrm{Al}_{2} \mathrm{O}_{3}$ ) $=0-35 \%$. At a certain $\mathrm{CaO} / \mathrm{SiO}_{2}$, the basicity does not change with additions of $\mathrm{TiO}_{2}$ or $\mathrm{Al}_{2} \mathrm{O}_{3}$.

(5) The basicity corresponding to this $\mathrm{CaO} / \mathrm{SiO}_{2}$ was termed the isoelectric point $(B i)$. At lower ratios of $\mathrm{CaO} / \mathrm{SiO}_{2}, B$ is increased by additions of $\mathrm{TiO}_{2}$ or $\mathrm{Al}_{2} \mathrm{O}_{3}$ and at higher ratios decreased. Thus, in terms of the isoelectric point the amphoteric behavior of slag constituents could be described quantitatively. It was suggested that $B i$ is decreased the more with increase of the metal-oxygen bond strength.

\section{REFERENCES}

(1) M. Ichinoe: J. Iron Steel Inst. Japan, 34 (1948) No. $4-6,4$

(2) W. L. Kerlie: J. Iron Steel Inst., 167 (1951) 9

(3) N. J. Grant, J. Chipman: Trans. AIME, $167(1946$ 134

(4) P. Herasymenko, G. E. Speight: J. Iron Steel Inst., $166(1950) 289$

(5) Kuan-Han Sun, A. Silverman: J. Amer. Ceram, Soc., 28 (1945) 8

6 Kuan-Han Sun: Glass Ind., 29 (1948) 73

( 7 J. Chipman, Lo-Ching Chang: Trans. AIME, 185 (1949) 191

(8) Kuan-Han Sun: J. Amer. Cerm. Soc., 30 (1947) 277

(9) R. Didtschenko, E. G. Rochow: J. Amer. Chem. Soc., 76 (1954) 3291

(10) H. Lux : Z. Elektrochem., 45 (1939) 303

(11) J. White: J. Iron Steel Inst., Carnegie Scholarship Memoirs, 27 (1938) 1

12 K. L. Fetters, J. Chipman: Trans. AIME, 145 (1941 95

(13) H. Larson, J. Chipman: J. Metals, 5 (1953) 1089

(14) K. Mori : J. Iron Steel Inst. Japan, 46 (1960) 548

(15) K. Mori : J. Japan Inst. Metals, 24 (1960 383 